Sains Malaysiana 50(9)(2021): 2675-2685

http://doi.org/10.17576/jsm-2021-5009-15

\title{
Assessment of Anti-Tyrosinase, Anti-Elastase and Anti-Acetylcholinesterase Properties of Fermented Mango Leaves at Different Maturity Level
}

(Penilaian Sifat Anti-Tirosinase, Anti-Elastase dan Anti-Asetilkolinesterase Daun Mangga yang Difermentasi pada Tahap Kematangan Berbeza)

\author{
Nur Diyana, A., Koh, S.P.*, Aziz, N., Hamid, N.S.A., Abdullah, R., Puteh, F. \& SARAh, S.
}

\begin{abstract}
Mango leaves are known to possess many health benefits but the industry only focused on mango fruit production, resulting in abundant leaves being underutilized. In this study, we managed to transform mango leaves into a new fermented drink, which has a pleasant taste through the bio-fermentation process. Different maturity levels of mango leaves were selected; premature leaves (light brown, LBML), intermediate mature leaves (light green, LGML) and mature leaves (green, ML), which were subjected to a fermentation process using bacteria and yeast. Tannin content, organic acids profile and various enzymes functionality activities (e.g. inhibition of tyrosinase, elastase and acetylcholinesterase) studies were determined on fermented mango leaves drink. The reduction of tannins content in all fermented mango leaves resulted in a less astringent taste as a consequence of the microbial action to break down tannins. Acetic, oxalic, kojic and quinic acid are some of the organic acids detected in fermented mango leaves that contributed to its slightly acidic taste. In comparison to non-fermented mango leaves, all fermented samples, particularly LBML drink showed a significant improvement $(P<0.05)$ in tyrosinase inhibition $(87.96 \%)$. Fermented mango leaves also exhibited good inhibition activity towards elastase (>80\%) and acetylcholinesterase (>90\%). Further histopathology examination on various rat's organs (kidney, liver, spleen, and stomach) showed no sign of inflammation symptoms. Through limit toxicological evaluation, the safety consumption rate $\left(I C_{50}\right.$ value) for fermented mango leaves was $1000 \mathrm{~mL} / 50 \mathrm{~kg}$ of human bodyweight. The improvement functionality activities of fermented mango leaves with a higher inhibition rate against tyrosinase, elastase, and acetylcholinesterase indicate its great potential as a food remedy for anti-ageing treatment.
\end{abstract}

Keywords: Organic acids; tannin content; toxicity effect

\section{ABSTRAK}

Daun mangga diketahui mempunyai banyak manfaat kesihatan tetapi industri hanya mementingkan pengeluaran buah mangga, menyebabkan banyak daun mangga yang tidak digunakan sebaiknya. Dalam kajian ini, kami berjaya menambahbaik daun mangga dengan menghasilkan minuman fermentasi baharu yang mempunyai rasa yang menyenangkan melalui proses bio-fermentasi. Daun mangga dengan kematangan yang berbeza telah dipilih: daun pramatang (coklat muda, LBML); daun matang perantaraan (hijau muda, LGML) dan daun matang (hijau, ML) dan menjalani proses penapaian menggunakan kultur campuran bakteria dan yis. Kandungan tanin, profil asid organik dan pelbagai aktiviti berfungsi enzim (contoh: perencatan tirosinase, elastase dan asetilkolinesterase) dikaji pada minuman mangga difermentasi. Pengurangan kandungan tanin pada semua daun mangga yang difermentasi telah menyebabkan kurang rasa pahit akibat tindakan penguraian tanin oleh mikroorganisma. Asid asetik, oksalat, kojik dan kuinik yang dikesan di dalam daun mangga difermentasi menyumbang kepada rasa yang bersifat sedikit berasid. Secara perbandingan, kepada daun mangga yang tidak difermentasi, terutamanya minuman LBML menunjukkan peningkatan $(P<0.05)$ terhadap perencatan tirosinase $(87.96 \%)$. Daun mangga yang difermentasi juga menunjukkan aktiviti perencatan yang baik terhadap aktiviti elastase (>8\%) dan asetilkolinesterase (>90\%). Tambahan pula, kajian histopatologi terhadap pelbagai organ tikus (buah pinggang, hati, limpa dan perut) menunjukkan tiada gejala keradangan. Melalui penilaian had keracunan toksikologi, kadar penggunaan selamat (nilai $I C_{50}$ ) untuk daun mangga terfermentasi adalah 
$1000 \mathrm{~mL} / 50 \mathrm{~kg}$ berat badan manusia. Peningkatan aktiviti berfungsi ke atas daun mangga difermentasi dengan kadar perencatan yang tinggi terhadap tirosinase, elastase dan asetilkolinesterase menunjukkan potensi yang besar sebagai makanan kesihatan untuk rawatan anti-penuaan.

Kata kunci: Asid organik; kandungan tanin; kesan kesitotoksikan

\section{INTRODUCTION}

Nowadays, many researchers chose to study natural ingredients that benefit human health. They utilize the abundant natural available resources to be converted into a variety of good health products. In this study, we chose mango leaves because of its abundant availability, which would always be dumped as an agri-waste. Mango or scientifically known as Mangifera indica is one of the commercial tropical fruits in Malaysia. However, mango trees need to be pruned frequently to enhance desirable shoot development, control of pest and diseases as well as to ease fruit harvesting work (Poffley \& Owens 2006). These processes left a significant amount of leaves underutilized.

Mango leaves have been reported to contain mangiferin compound, which was known to have plenty of advantages like anti-ageing, antidiabetic, antioxidant, anti-tumour and anti-viral (Kulkarni \& Rathod 2018). Mangiferin is one of the natural phytochemicals that act as a potential human anti-ageing compound (Song et al. 2013). Ageing is a complex biological process characterized by a gradual loss of physiological functions and increased vulnerability to death. According to Rasul et al. (2012), skin ageing was caused by a constant exposure to ultraviolet irradiation that resulted in damaging the human skin. Tyrosinase is an enzyme with multifunctional, glycosylated, copper-containing oxidase that catalyses the conversion of melanin and other pigments from tyrosine by the oxidation process, which are responsible for dark skin formation. It is located inside the melanosomes and synthesized in the melanocytes ( Tu \& Tawata 2015). Inhibition of tyrosinase can prevent the formation of melanin as the overproduction of melanin may lead to skin disorder disease (Ebanks et al. 2009).

Thus, tyrosinase inhibition is one of the best ways to overcome dark skin problem. Elastase is another important skin enzyme, which plays a role in breaking down elastin structure in the skin and causing wrinkle formation. The inhibition of elastase enzymes helps in preventing loss of skin elasticity and combat skin ageing development. Findings from Ochocka et al. (2017) showed that mangiferin has the ability to inhibit the catalytic activity of elastase, which is responsible for skin ageing. Furthermore, ageing also plays a part in most neurodegenerative diseases like Alzheimer's disease. Acetylcholinesterase is an enzyme that catalyzed the breakdown of acetylcholine that functions as a neurotransmitter, a chemical produced by nerve cells or neurons. To date, there is no particular medicine for Alzheimer's treatment. However, drugs involved in the inhibition of cholinesterase are commonly prescribed to treat the disease. Acetylcholinesterase inhibitor is an effective compound, which plays a defensive role in cognitive disorder treatment like Alzheimer's, senile, dementia, ataxia, myasthenia gravis, and Parkinson's diseases (Colovic et al. 2013). However, in recent years, accumulating evidence has shown that mangiferin in mango leaves contains potential neuroprotective properties that can contribute to reducing the ageing problem. Furthermore, mangiferin also has the potential function in preventing neurological damage and dementia as well as improving learning and memory impairment as shown in the senescence-accelerated mouse model (Du et al. 2019). Therefore, the acetylcholinesterase inhibitor offers a therapeutic alternative for Alzheimer's treatment.

In this study, mango leaves were fermented with selected mixed cultures of Komagataiebacter sp. bacteria and Dekkera sp. yeast with the aim to improve the functional properties of mango leaves. Microbial fermentation could help to enhance the benefits of mango leaves and improve the organoleptic properties of fermented end products. According to Jayabalan et al. (2014), the fermentation process improved the functionality of natural source products in Kombucha tea. Similarly, Faria-Oliveira et al. (2015) have shown that the fermentation process is one of the food processing techniques commonly used to improve the final product with better taste and aroma through microbiological activity. During the fermentation, microorganisms like yeast produce some metabolites that may contribute to 
the desired aromatic and flavour compounds with the presence of a certain amount of ethanol. Concurrently, acetic acid bacteria will metabolize the alcohol produced by yeast into organic acids. Other metabolites produced during the fermentation are simple sugars and carbon dioxide (Neffe-Skoci'nska et al. 2017). The toxicological study on fermented mango leaves was also investigated to ensure the safety aspect of consuming this fermented mango leave beverage.

\section{MATERIALS AND METHODS}

\section{PLANT MATERIAL AND FERMENTATION PREPARATION}

The mango leaves from Mangifera indica Chokanan variety were collected from MARDI mango plot in Serdang (Selangor, Malaysia). The leaves were washed to remove dirt and were oven-dried in a fabricated dryer at $40{ }^{\circ} \mathrm{C}$ for $48 \mathrm{~h}$. The dried leaves were then milled using an ultra-centrifugal mill (Retsch, ZM 200, Haan, Germany) at $0.5 \mathrm{~mm}$ of particle size and vacuum-packed before storing at $4{ }^{\circ} \mathrm{C}$ for future use. Mango leaves with different stages of maturity were selected; premature leaves (light brown, LBML); intermediate mature leaves (light green, LGML) and mature leaves (green, ML) as described in Figure 1. Mango leaves were fermented with selected symbiotic cultures of bacteria (Komagataiebacter sp.) and yeast (Dekkera sp.), known as SCOBY for eight days in incubator shaker (New Brunswick ${ }^{\mathrm{TM}}$ Innova $^{\circledR} 42 / 42 \mathrm{R}$, Eppendorf AG, Germany) with a controlled temperature at $30{ }^{\circ} \mathrm{C}$. The fermented mango leaves were centrifuged at 10,000 rpm for $5 \mathrm{~min}$ (Centrifuge $5810 \mathrm{R}$, Eppendorf, Germany) to collect the supernatant by removing the microbe and substrate residue. The $\mathrm{C} 0$ and D8 were denoted as non-fermented mango leaves and fermented mango leaves, respectively.

\section{EVALUATION OF TANNIN CONTENT OF FERMENTED MANGO LEAVE}

The tannin content of fermented mango leaves was determined using spectrophotometric Folin-Ciocalteu method with gallic acid as a standard (Tambe \& Bhambar 2014). Approximately, $0.1 \mathrm{~mL}$ of fermented mango leaves extract was added into a volumetric flask containing $7.5 \mathrm{~mL}$ of distilled water, $0.5 \mathrm{~mL}$ FolinCiocalteu-phenol reagent, $1 \mathrm{~mL}$ of $35 \% \mathrm{Na}_{2} \mathrm{CO}_{3}$ solution before diluted with $10 \mathrm{~mL}$ distilled water. The mixture was thoroughly shaken and kept at room temperature for
$30 \mathrm{~min}$. The absorbance was measured at $725 \mathrm{~nm}$ using a UV visible spectrophotometer (Varian Cary ${ }^{\circledR} 50$ Conc UV-Vis spectrophotometer, Varian Inc., USA).

\section{EVALUATION OF ORGANIC ACIDS OF FERMENTED MANGO LEAVES}

Organic acids profile of fermented mango leaves was performed with high-performance liquid chromatography (HPLC), Alliance Separation Module (Waters, 2695), equipped with a diode array detector (Waters, 2996) and the running parameter was conducted according to the procedure as described in Koh et al. (2019). The quantification of the organic acids was determined by the individual organic acid standard calibration curve. All analysis was done in triplicate.

\section{EVALUATION OF ENZYME FUNCTIONALITY ACTIVITIES OF FERMENTED MANGO LEAVES}

\section{EVALUATION OF TYROSINASE INHIBITION OF FERMENTED MANGO LEAVE}

The inhibition of tyrosinase activity of fermented mango leaves was measured using L-DOPA as a substrate and kojic acid as a positive control according to the method by Suganya et al. (2015) with minor modification. Tyrosinase and L-DOPA were used as the enzyme and substrate, respectively. About $40 \mu \mathrm{L}$ of $5 \mathrm{mML}$-DOPA was mixed with $100 \mu \mathrm{L}$ of $0.1 \mathrm{M}, \mathrm{pH} 6.8$ phosphate buffer in a 96-wells microtiter plate. The mixture was thoroughly mixed and incubated at $37^{\circ} \mathrm{C}$ for $10 \mathrm{~min}$. About $120 \mu \mathrm{L}$ of fermented mango leaves extract and $40 \mu \mathrm{L}$ of tyrosine (62 U/mL in $0.1 \mathrm{M}, \mathrm{pH} 6.8$ phosphate buffer) were added and incubated at $37^{\circ} \mathrm{C}$ for $10 \mathrm{~min}$ before the absorbance was measured at $475 \mathrm{~nm}$ using the Varian Cary ${ }^{\circledR} 50$ Conc UV-Vis spectrophotometer (Varian Inc., USA). All the enzyme inhibitory activities were expressed in the percentage of inhibition (\%).

Tyrosinase inhibition activity $(\%)=\underline{(\text { Abs control }-[\text { Abs sample-Abs sample blank }]) \times 100}$ Abs control

\section{EVALUATION OF ELASTASE INHIBITION OF FERMENTED MANGO LEAVE}

Elastase inhibitory activity of fermented mango leaves was performed according to the procedure by Liyanaarachchi et al. (2018) with slight modification, 
which involved the use of porcine pancreatic elastase (PPE). The epigallocatechin-3-gallate (EGCG) was used as positive control while the oleanolic acid was used as a standard. A $50 \mu \mathrm{L}$ of the sample was added with 50 $\mu \mathrm{L}$ elastase dissolved in $0.2 \mathrm{mM}$ Tris HCI buffer $(\mathrm{pH}$ 8 ). The mixture was thoroughly mixed and pre-treated at $25{ }^{\circ} \mathrm{C}$ for $10 \mathrm{~min}$ before N-Succinyl-Ala-Ala-Alap-Nitroanilide (AAAPVN) solution were added and incubated at $25{ }^{\circ} \mathrm{C}$ for another $30 \mathrm{~min}$ in a dark condition. The absorbance was measured at $410 \mathrm{~nm}$ using the UV visible spectrophotometer (Varian Cary ${ }^{\circledR} 50$ Conc UVVis spectrophotometer, Varian Inc., USA). All the enzyme inhibitory activities were expressed in the percentage of inhibition (\%) using the equation stated herewith:

Elastase inhibition activity $(\%)=\underline{(\text { Abs control }-[\text { Abs sample }- \text { Abs sample blank }]) \times 100}$

Abs control

\section{EVALUATION OF ACETYLCHOLINESTERASE (ACHE)} INHIBITION OF FERMENTED MANGO LEAVE

The inhibition of acetylcholinesterase activity of mango leaves was measured as described by Ellman et al. (1961) with some modification. Approximately 100 $\mu \mathrm{L}$ sample was added into $20 \mu \mathrm{L}$ acetylcholinesterase dissolved in $0.1 \mathrm{M}$ phosphate buffer, $\mathrm{pH}$ 7.4. The mixture was thoroughly vortexed before $120 \mu \mathrm{L}$ Ellman reagent were added. After $2 \mathrm{~min}$ reaction, $30 \mu \mathrm{L} 25 \mathrm{mM}$ ATCI solution was added and incubated at $25{ }^{\circ} \mathrm{C}$ for $30 \mathrm{~min}$. The absorbance was measured immediately using the UV visible spectrophotometer at $412 \mathrm{~nm}$ (Varian Cary ${ }^{\circledR} 50$ Conc UV-Vis spectrophotometer, Varian Inc., USA). The acetylcholinesterase activity was assayed in triplicate and Tacrine was used as a standard. All the enzyme inhibitory activities were expressed in the percentage of inhibition (\%) as in the equation herewith:

AChE inhibition activity $(\%)=\underline{(\text { Abs control }-[\text { Abs sample }- \text { Abs sample blank }]) \times 100}$

Abs control

\section{TOXICITY ASSESSMENT ON RATS FED WITH FERMENTED MANGO LEAVES}

The limit test was performed on 5 female Sprague Dawley rats fed with fermented mango leaves according to $\mathrm{OECD} / \mathrm{OCDE}$ test guideline 407 . The rats were orally forced fed with $200 \mathrm{mg} / \mathrm{kg}$ bodyweight fermented product on Day 1. The feeding was increased by $200 \mathrm{mg} /$ $\mathrm{kg}$ of bodyweight per day until the rats showed signs of toxicity. The toxicity symptoms were monitored daily by observing the behavioural and physical changes (hyperactivity, tremors, ataxia, salivation, diarrhoea, lethargy, and sleep pattern) of the rats. Histopathology analysis was conducted on various organs (kidneys, liver, spleen, and stomach). All organs were fixed into $10 \%$ of formalin, a natural buffer solution before being preserved with paraffin to prepare organ sections. The organs were stained with haematoxylin and eosin (H\&E), which were then observed under a microscope (Leica, Germany). This animal study was approved and conducted according to the guidelines by the Animal Ethics Committee of MARDI (20170420/R/MAEC 00007).

\section{STATISTICAL ANALYSIS}

The experiment was completed with three replicates and the results were presented as mean \pm standard deviation. The data obtained were analysed statistically using one-way analysis of variance (ANOVA) and multiple comparisons were performed by Duncan's test. Statistical significance was set at the level of $P<0.05$. The data analysis was conducted using statistical analysis software, IBM SPSS Statistic 22.0 (IMB Corp., USA).

\section{RESULTS AND DISCUSSION}

In the present study, three types of mango leaves comprising of premature leaves (light brown, LBML), intermediate mature leaves (light green, LGML), and mature leaves (green, ML) were selected to produce fermented mango leaves through the bio-fermentation process under a controlled condition using mixed cultures of bacteria and yeast. The study of functionality activities was carried out on selected fermented mango leaves, including tannin content, organic acids profile, inhibition of skin pigmentation, evaluation of anti-wrinkle capacity, and inhibition of acetylcholinesterase. The maturity level of Mangifera indica Chokanan leaves was determined according to leaves colour changes as described in Figure 1: A) premature leaves (light brown, LBML), B) intermediate mature leaves (light green, LGML) and C) mature leaves (green, ML).

The tannin content in mango leaves may affect the palatability of the extract since it contributes to bitter taste (Wurger et al. 2014). As the maturity of mango leaves progressed from premature to mature leaves, the tannin content increased significantly (Figure 2), whereby, the non-fermented mature green leaves (ML C0) contained 
the highest amount of tannin (3.09 $\mathrm{mg} \mathrm{GA} / \mathrm{mL})$. Generally, all fermented mango leaves displayed a significant reduction in tannin content after going through the microbial fermentation process. Both fermented mango leaves (LGML D8 and LBML D8) showed the lowest tannin content $(>1 \mathrm{GA} / \mathrm{ml})$ compared to fermented ML D8. The tannin content in all fermented mango leaves was significantly reduced compared to non-fermented mango leaves. This phenomenon may occur due to the presence of microbial enzymes secreted during the microbial fermentation process, which helped to breakdown the tannin content in the leaves, consequently, contribute to the favourable taste of fermented mango leaves (Ashok \& Upadhyaya 2012). In comparison, fermented premature mango leaves (LGML D8) have lower tannin content than mature leaves, which indirectly contribute to the less astringent and bitter taste compared to fermented mango mature leaves.

Several organic acids were detected in fermented mango leaves, including acetic acid, oxalic acid, kojic acid, and quinic acid (Table 1). During fermentation, acetic acid was produced in a significant amount compared to other organic acids when using different maturity level of mango leaves (LGML D8; LBML D8; ML D8) as a substrate and yielded approximately $19396.08 \pm 3016.30,16855.80 \pm$ 993.01, and $16565.80 \pm 1493.60 \mathrm{ppm}$, respectively. Among the three different types of fermented mango leaves, only ML D8 produced quinic acid with a concentration of $524.29 \pm 8.84 \mathrm{ppm}$. During the fermentation, numerous biochemical reactions occurred as a result of symbiotic cultures of bacteria and yeast (SCOBY) fermentation involved in the alcoholic and acidification process. The accumulation of acetic acid was due to the metabolism of acetic acid bacteria Komagataiebacter sp., which is the main metabolite produced during the fermentation of mango leaves. The increment of acetic acid during the SCOBY fermentation was also observed by NeffeSkocinska et al. (2017). In contrast, the lowest content of oxalic acid and kojic acid were produced in fermented mango leaves, ML D8 samples $(24.93 \pm 1.00$ and $3.30 \pm$ $0.24 \mathrm{ppm}$, respectively) compared to other fermented LBML D8 and LGML D8 samples. This finding indicated that the maturity level of mango leaves could influence the concentration of the organic acids during the fermentation process. Oxalic acid, which is one of the organic acids involved in energy metabolism was detected in fermented mango leaves (Watawana et al. 2015). Kojic acid is another valuable metabolite produced during the fermentation, which has a whitening effect on the skin (Tang \& Yang 2018; Taylor et al. 2013). The presence of kojic acid in the fermented mango leave is one of the anti-pigmentation contributing factors for the consequence finding in tyrosinase inhibition of this study.

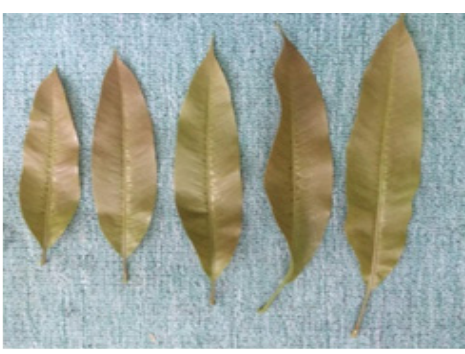

(A)

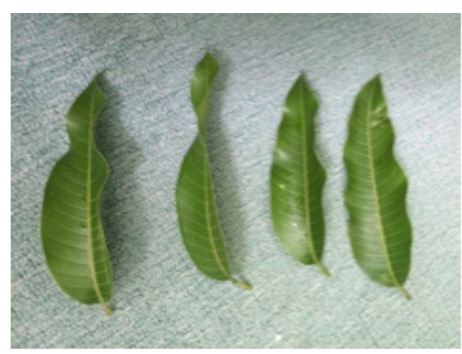

(B)

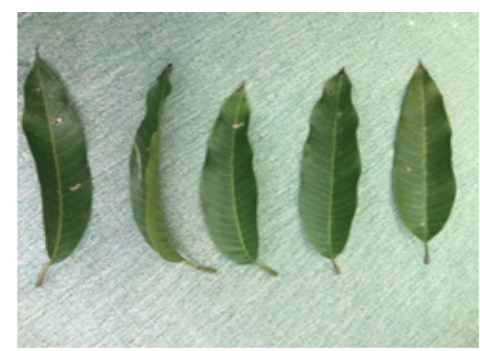

(C)

FIGURE 1. Three maturity level of Mangifera indica Chokanan leaves: A) premature leaves (light brown, LBML); B) intermediate mature leaves (light green, LGML) and C) mature leaves (green, ML) 


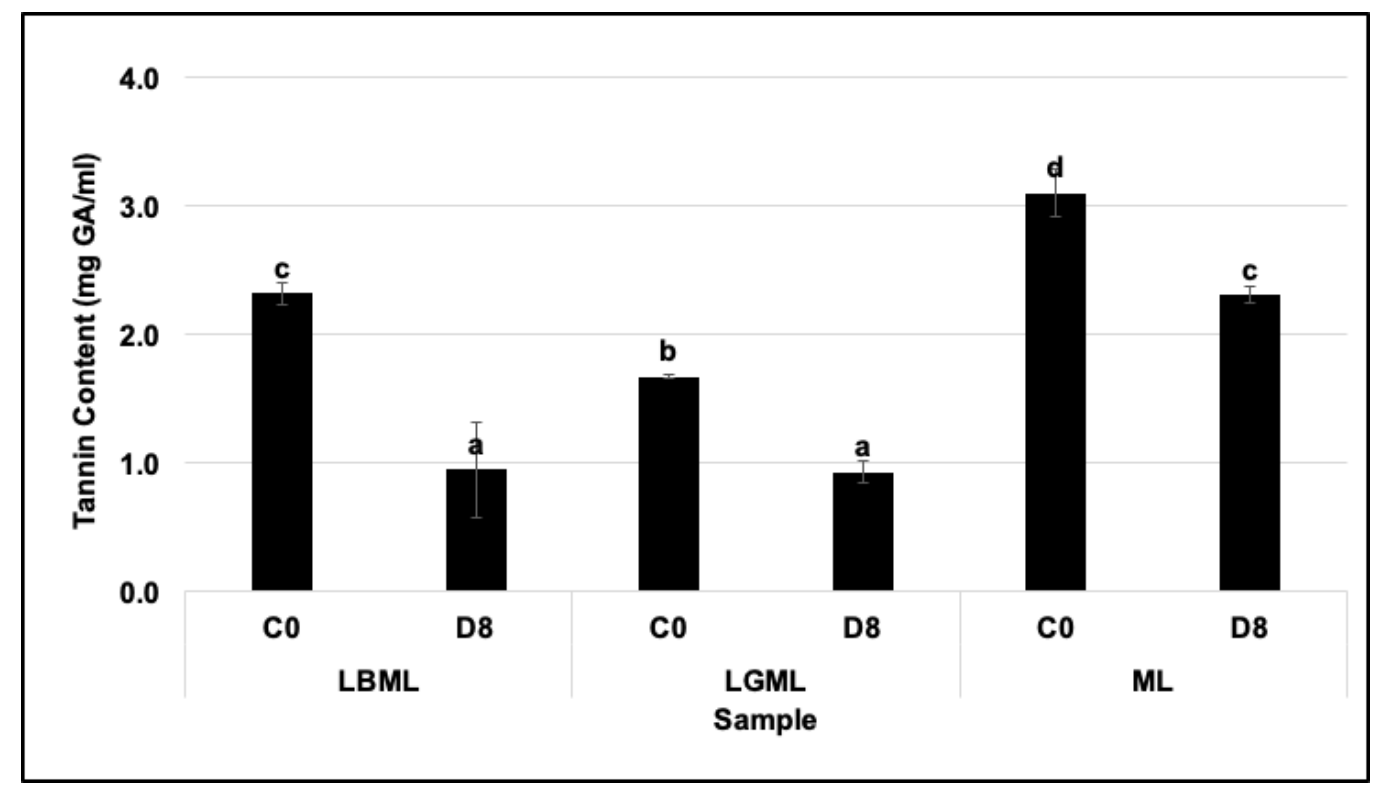

FIGURE 2. Tannin content of SCOBY fermented and non-fermented mango leaves

LBML D8 (fermented light brown leaves), LBML C0 (non-fermented light brown leaves), LGML D8 (fermented light green leaves), LGML C0 (non-fermented light green leaves), ML D8 (fermented green leaves) and ML C0 (non-fermented green leaves)

TABLE 1. Organic acids profile of SCOBY fermented mango leaves

\begin{tabular}{lcccc}
\hline Sample & $\begin{array}{c}\text { Acetic acid } \\
(\mathrm{ppm})\end{array}$ & $\begin{array}{c}\text { Oxalic acid } \\
(\mathrm{ppm})\end{array}$ & $\begin{array}{c}\text { Kojic acid } \\
(\mathrm{ppm})\end{array}$ & $\begin{array}{c}\text { Quinic acid } \\
(\mathrm{ppm})\end{array}$ \\
\hline LBML (D8) & $16855.80 \pm 993.01$ & $38.49 \pm 1.02$ & $7.31 \pm 0.79$ & $0.00 \pm 0.00$ \\
LGML (D8) & $19396.08 \pm 3016.30$ & $37.16 \pm 4.83$ & $7.75 \pm 0.36$ & $0.00 \pm 0.00$ \\
ML (D8) & $16565.80 \pm 1493.6$ & $24.93 \pm 1.00$ & $3.30 \pm 0.24$ & $524.29 \pm 8.84$ \\
\hline
\end{tabular}

LBML D8 (fermented light brown leaves), , LGML D8 (fermented light green leaves), ML D8 (fermented green leaves)

Tyrosinase inhibitor is one of the valuable whitening agent present in skincare products. From the functional enzymes analysis, the fermented mango leaves at different maturity levels were demonstrated to have higher tyrosinase inhibitory activity compared to non-fermented mango leaves (Figure 3(A)). All three nonfermented mango leaves, LBML C0, LGML C0, and ML C0 exhibited lower tyrosinase inhibitory activity at $48.25 \%$, $51.91 \%$, and $36.22 \%$, respectively. Surprisingly, all fermented mango leaves showed a significant increment of tyrosinase inhibition activities than non-fermented 
mango leaves. Among all mango leaves sample tested, the LBML D8 sample emerged as the highest tyrosinase inhibitory activity $(87.96 \%)$ compared to LGML D8 and ML D8 samples, which only have $80.90 \%$ and $79.93 \%$ inhibitory activities, respectively. The positive control of kojic acid was shown to have tyrosinase inhibitory activity of $86.35 \%$, which was comparable to LBML D8 sample. Most of the commercial anti-pigmentation skincare product contains a tyrosinase inhibitor because it helps to prevent excessive melanin production. Similar findings by Shi et al. (2020) also demonstrated that ethyl acetate fraction of mango leaves have strong tyrosinase inhibitory activity with the $\mathrm{IC}_{50}$ value of $17.62 \pm 1.26 \mu \mathrm{g} / \mathrm{mL}$.

Similarly, the percentage of elastase inhibitory activity of all fermented mango leaves samples were higher than non-fermented mango leaves (Figure 3(B)) and showed comparable effectiveness as a positive control sample, oleanolic acid. The oleanolic acid is a skin-protective pentacyclic triterpene and was used as a positive control due to its positive inhibitory activity against elastase ( $\mathrm{Tu} \&$ Tawata 2015). In this study, it was found that all non-fermented mango leaves showed high elastase inhibitory activity, which indicated that mango leaves itself is a good source of elastase inhibitor. However, all fermented mango leaves were noted to have slight improvement of elastase inhibitory activity than non-fermented counterpart (Figure 3(B)), whereby, the inhibition rate of LBML D8, LGML D8 and ML D8 reached $88.65 \%, 91.79 \%$, and $91.55 \%$, respectively. Both non-fermented and fermented mango leaves displayed a significantly higher percentage of elastase inhibition than oleanolic acid (69.27\%). These results indicated that different maturity level of mango leaves naturally possess anti-elastase activity and fermentation process, further improving its elastase inhibitory activity. The similar findings were also reported by Ochocka et al. (2017), which showed that the mangiferin could completely inhibit elastase activity at the mangiferin concentrations above $473 \mu \mathrm{M}$. Generally, fermented mango leaves showed significant improvement in both tyrosinase and elastase inhibitory effects than non-fermented mango leaves counterpart, which indicates the potential of fermented mango leaves as a new tyrosinase and elastase inhibitor that can be incorporated in skincare products to manage ageing development related to pigmentation and skin wrinkle problem.

Currently, acetylcholinesterase inhibitor was used as an alternative treatment for Alzheimer's patient to reduce the breakdown of acetylcholine by acetylcholinesterase. Briefly, the LGML D8 sample showed the best inhibitory effect on enzyme acetylcholinesterase (96.51\%), followed by ML D8 (96.06\%), and LBML D8 $(95.31 \%)$ as displayed in Figure 3(C). This finding indicated that fermented mango leaves could be a potential acetylcholinesterase inhibitor, which showed the capability to inhibit this enzyme from breaking down acetylcholine when it travels from one cell to another. There is a slight increment of acetylcholinesterase enzyme inhibitory activity in fermented mango leaves as oppose to non-fermented mango leaves (Figure $3(\mathrm{C})$ ). According to Jung et al. (2009) and Wightman et al. (2020), the presence of mangiferin in mango leaves extract may contribute to a significant role in the inhibition of acetylcholinesterase. An investigation by Sethiya and Mishra (2014) suggested that mangiferin is one of the promising compounds targeted for Alzheimer's disease treatment as past research finding has reported that mangiferin significantly inhibited $\mathrm{AChE}$ with the $\mathrm{IC}_{50}$ value of $55.42 \pm 1.52 \mu \mathrm{g} / \mathrm{mL}$ and protects the loss of acetylcholine. The decrease content of acetylcholine is responsible for cognitive function degradation and progression of Alzheimer's diseases. Generally, all fermented mango leaves samples gave a potent inhibition of acetylcholinesterase of more than $90 \%$, significantly showed a higher inhibitory effect $(P<0.05)$ than Tacrine $\mathrm{HCl}$.

The safety aspect of consuming fermented mango leaves was also investigated. Histopathology analyses on various organ tissues (liver, kidneys, spleen, and stomach) were carried out to evaluate the toxicity effect on rats treated with fermented mango leaves (Figure 4). Limit toxicology test analysis on rats was conducted by subjecting the rats to a daily increment of dosage consumption at $200 \mathrm{mg} / \mathrm{kg}$ of bodyweight interval until the rats showed signs of toxicity. When the rats start to show abnormal physical behaviours, the rats were sacrificed in the $\mathrm{CO}_{2}$ chamber and various organs were harvested for histopathological analysis. Generally, there was no sign of inflammation symptoms observed in all treated rat's organs tissue indicating no toxicity effect occurred in rats fed with fermented mango leaves. Based on the data collected from the limit test analysis, it was identified that the $\mathrm{IC}_{50}$ value, safety dosage of fermented mango leaves was $1000 \mathrm{~mL} / 50 \mathrm{~kg}$ of bodyweight, which indicated that fermented mango leaves are safe for consumption at the recommended dosage of $60 \mathrm{~mL} / 50$ 


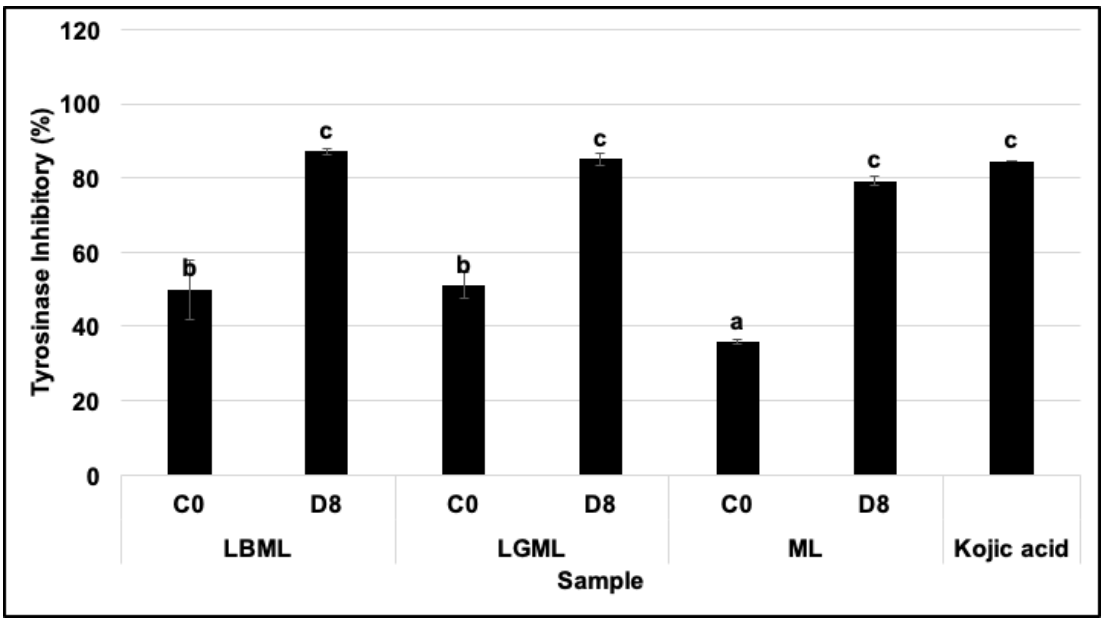

(A)

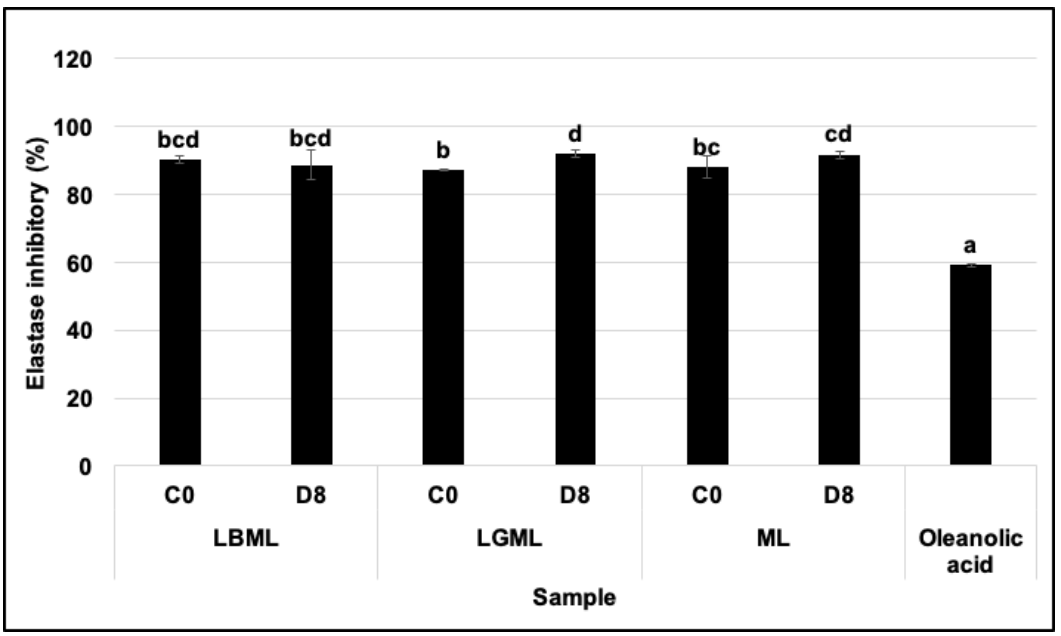

(B)

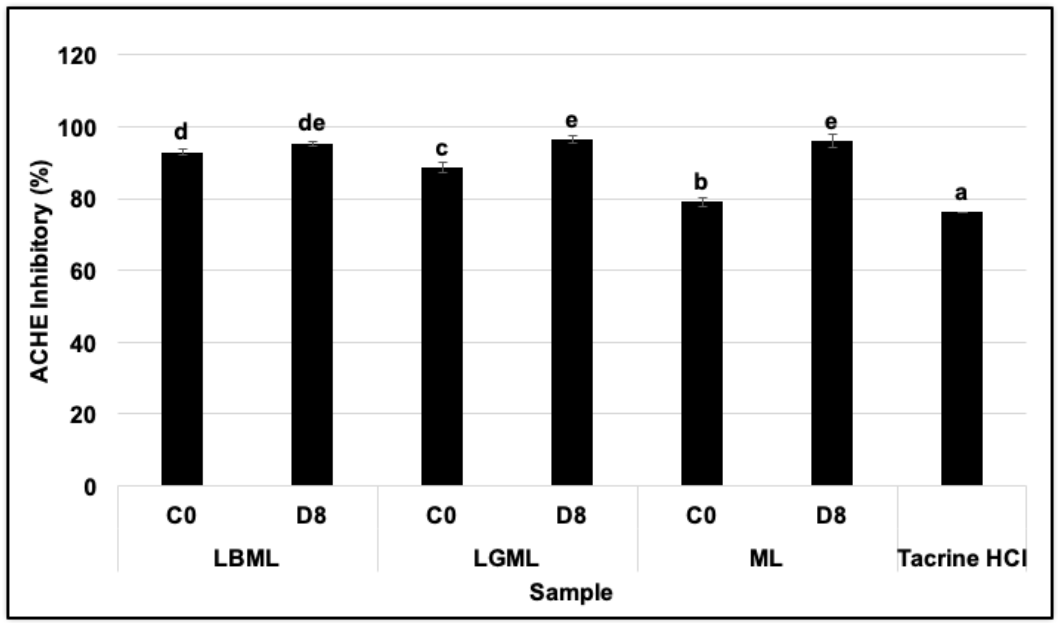

(C)

FIGURE 3. Functionality activities of fermented and non-fermented mango leaves. (A) Tyrosinase, (B) Elastase and (C) Acetylcholinesterase inhibitory activities (\%)

LBML D8 (fermented light brown leaves), LBML C0 (non-fermented light brown leaves), LGML D8 (fermented light green leaves), LGML C0 (non-fermented light green leaves), ML D8 (fermented green leaves) and ML C0 (non-fermented green leaves) 


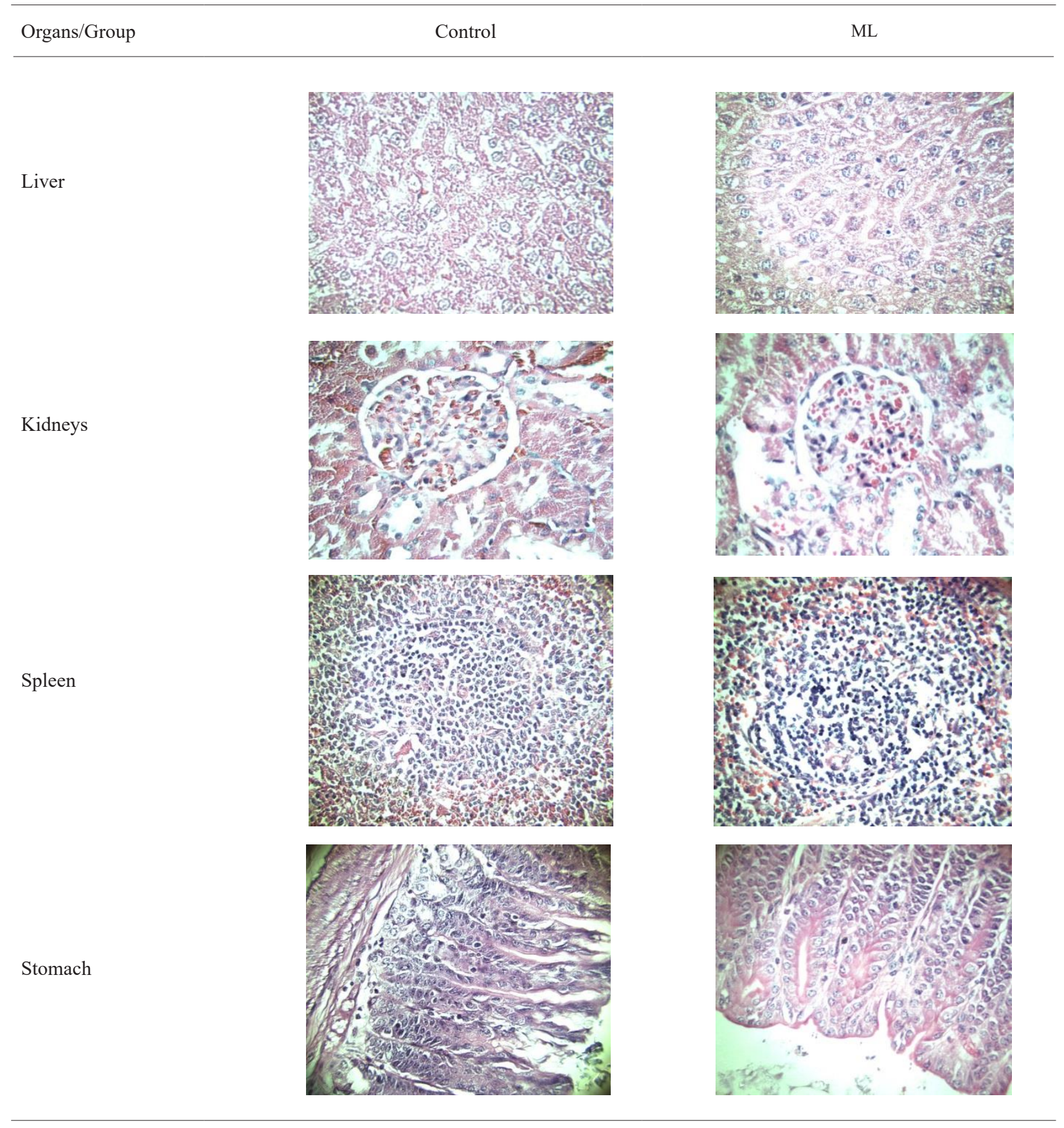

FIGURE 4. Observation of histopathological analysis of the Sprague Dawley rat's organ for the control group and fermented mango leaves treatment group with 100X magnification

$\mathrm{kg}$ of bodyweight.

\section{CONCLUSION}

The notable reduction of tannin content but increased in organic acids content in all fermented mango leaves have improved the mouthfeel with less unpleasant taste as a consequence of microbial action. Fermented mango leaves were confirmed to have higher tyrosinase, elastase, and acetylcholinesterase inhibitory activity, which indicate its 
potential to regulate the process of pigmentation, ageing, and neurodegenerative diseases, respectively. No toxicity effect was observed in rats fed with fermented mango leaves with the evidence supported by the histopathology results.

\section{ACKNOWLEDGEMENTS}

This study was supported by Horticulture Research Centre, MARDI and financially funded by Malaysia Government Development Fund RMK-11 (P21003004050001) research grant.

\section{REFERENCES}

Ashok, P.K. \& Upadhyaya, K. 2012. Tannins are astringent. Journal of Pharmacognosy and Phytochemistry 1(3): 45-50.

Colovic, M.B., Krstic, D.Z., Lazarevic-Pasti, T.D., Bondzic, A.M., Vesna, M. \& Vasić, V.M. 2013. Acetylcholinesterase inhibitors: Pharmacology and toxicology. Current Neuropharmacology 11(3): 315-335.

Du, Z., Fanshi, F., Lai, Y.H., Chen, J.R., Hao, E., Deng, J. \& Hsiao, C.D. 2019. Mechanism of anti-dementia effects of mangiferin in a senescence-accelerated mouse (SAMP8) model. Bioscience Reports 39(9): BSR20190488.

Ebanks, J.P., Wickett, R.R. \& Boissy, R.E. 2009. Mechanisms regulating skin pigmentation: The rise and fall of complexion coloration. International Journal of Molecular Sciences 10(9): 4066-4087.

Ellman, G.L., Courtney, K.D., Andres Jr., V. \& Featherstone, R.M. 1961. A new and rapid colorimetric determination of acetylcholinesterase activity. Biochemical Pharmacology 88-90: 91-95.

Faria-Oliveira, F., Diniz, R.H.S., Godoy-Santos, F., Pilo, F.B., Mezadri, H., Castro, I.M. \& Brandao, R.L. 2015. The Role of Yeast and Lactic Acid Bacteria in the Production of Fermented Beverages in South America. https://www. intechopen.com/books/food-production-and-industry/therole-of-yeast-and-lactic-acid-bacteria-in-the-production-offermented-beverages-in-south-america.

Jayabalan, R., Malbasa, R.V., Loncar, E.S., Vitas, J.S. \& Sathishkumar, M. 2014. A review on Kombucha tea Microbiology, composition, fermentation, beneficial effects, toxicity and tea fungus. Comprehensive Review in Food Science and Food Safety 13(4): 538-550.

Jung, K., Lee, B., Han, S.J., Ryu, J.H. \& Kim, D.H. 2009. Mangiferin ameliorates scopolamine-induced learning deficits in mice. Biological and Pharmaceutical Bulletin 32: 242-246.

Koh, S.P., Sharifudin, S.A., Abdullah, R.A., Hamid, N.S., Mirad, R. \& Mustaffa, R. 2019. Antimicrobial efficacy of fermented mango leaves beverage towards selected foodborne pathogens. Malaysian Journal of Microbiology 15(4): 320-326.
Kulkarni, V.M. \& Rathod, V.K. 2018. Exploring the potential of Mangifera indica leaves extract versus mangiferin for therapeutic application. Agriculture and Natural Resources 52(2): 155-161.

Liyanaarachchi, G.D., Samarasekara, J.K.R.R., Mahanama, R. \& Hemalal, P. 2018. Tyrosinase, elastase, hyaluronate ideas, inhibitory and antioxidant activity of Sri Lankan medicinal plants for novel cosmeceuticals. Industrial Crops and Products 111: 597-606.

Neffe-Skoci'nska, K., Sionek, B., Scibisz, I. \& Koło'zynKrajewska, D. 2017. Acid contents and the effect of fermentation condition of Kombucha tea beverages on physicochemical, microbiological and sensory properties. Journal of Food 15: 601-607.

Ochocka, R., Hering, A., Stefanowicz-Hajduk, J., Cal, K. \& Baraska, H. 2017. The effect of mangiferin on skin: Penetration, permeation and inhibition of ECM enzymes. PLoS ONE https://journals.plos.org/plosone/ article?id=10.1371/journal.pone. 0181542 .

Poffley, M. \& Owens, G. 2006. Mango pruning in the top end. In Northern Territory of Australia www.nt.gov.au/dpifm. p. 4. Accessed on 30 July 2019.

Rasul, A., Akhtar, N., Khan, B.A., Mahmood, T., Uz Zaman, S. \& Khan, H.M. 2012. Formulation development of a cream containing fennel extract: In vivo evaluation for anti-ageing effects. Pharmazie 67: 54-58.

Sethiya, N.K. \& Mishra, S. 2014. Investigation of mangiferin, as a promising natural polyphenol xanthone on multiple targets of Alzheimer's disease. Journal of Biologically Active Products from Nature 4: 111-119.

Shi, F., Xie, L., Lin, Q., Tong, C., Fu, Q., Xu, J., Xiao, J. \& Shi, S. 2020. Profiling of tyrosinase inhibitors in mango leaves for a sustainable agro-industry. Food Chemistry 312: 126042.

Song, J.H., Bae, E.Y., Choi, G., Hyun, J.W., Lee, M.Y., Lee, H.W. \& Chae, S. 2013. Protective effect of mango (Mangifera indica L.) against UVB-induced skin ageing in hairless mice. Photodermatology, Photoimmunology and Photomedicine 29(2): 84-89.

Suganya, P., Karnan, J., Mallavarapu, G.R. \& Murugan, R. 2015. Comparison of the chemical composition, tyrosinase inhibitory and anti-inflammatory activities of the essential oils of Pogostemon plectranthodes from India. Industrial Crops and Products 69: 300-307.

Tambe, V.D. \& Bhambar, R.S. 2014. Estimation of total phenol, tannin, alkaloid and flavonoid in Hibiscus tiliaceus Linn. Wood extracts. Research \& Reviews: Journal of Pharmacognosy and Phytochemistry 2(4): 41-47.

Tang, S.C. \& Yang, J.H. 2018. Dual effects of alpha-hydroxy acids on the skin. Molecules 23(4): 863

Taylor, M.B., Yanaki, J.S., Draper, D.O., Shurtz, J.C. \& Coglianese, M. 2013. Successful short-term and long-term treatment of melasma and postinflammatory hyperpigmentation using vitamin $\mathrm{C}$ with a full-face 
iontophoresis mask and a mandelic/malic acid skin care regimen. Journal of Drugs Dermatology 12(1): 45-50.

Tu, P.T.B. \& Tawata, S. 2015. Anti-oxidant, anti-aging, and anti-melanogenic properties of the essential oils from two varieties of Alpinia zerumbet. Molecules 20(9): 16723-16740.

Wightman, E.L., Jackson, P.A., Forster, J., Khan, J., Wiebe, J.C., Gericke, N. \& Kennedy, D.O. 2020. Acute effects of a polyphenol-rich leaf extract of Mangifera indica L. (Zynamite) on cognitive function in healthy adults: A double-blind, placebo-controlled crossover study. Nutrients 12(8): 2194.

Watawana, M.I., Jayawardena, N., Gunawardhana, C.B. \& Waisundara, V.Y. 2015. Health, wellness, and safety aspects of the consumption of Kombucha. Journal of Chemistry 2015: Article ID. 591869
Wurger, G., McGaw, L.J. \& Eloff, J.N. 2014. Tannin content of leaf extracts of 53 trees used traditionally to treat diarrhoea is an important criterion in selecting species for further work. South African Journal of Botany 90: 114-117.

Food Science \& Technology Research Centre

Malaysian Agricultural Research and Development (MARDI)

Persiaran MARDI-UPM

43400 Serdang, Selangor Darul Ehsan

Malaysia

*Corresponding author; email: karenkoh@mardi.gov.my

Received: 11 April 2020

Accepted: 10 January 2021 